\title{
ROPN1 Gene
}

National Cancer Institute

\section{Source}

National Cancer Institute. ROPN1 Gene. NCI Thesaurus. Code C143008.

This gene plays a role in spermatozoa capacitation. 